\title{
ENKELE GEDAGTES OOR DIE KRISIS IN DIE NATUURWETENSKAP.
}

Waarom word wetenskap vandag nog beoefen? Dat so 'n vraag gestel kan word is nie alleen 'n teken van die tyd maar tegelykertyd 'n waarskuwing. 'n Waarskuwing aan die adres van die wetenskap om terug te keer tot sy eintlike taak. Dié taak is, egter, nie slegs 'n versameling van kennis nie-hoe noodsaaklik en belangrik die ook mag wees. Vandag is dit, egter, die geval dat hierdie opeenstapeling van kennis in die wetenskaplike wêreld 'n ontsaglike omvang aanneem wat as noodwendige gevolg moet hê ' $n$ daling in die agting vir die wetenskaplike verrigtinge. Hier mag miskien die ernstige woord van Schopenhauer toepaslik wees: „In den Wissenschaften will jeder, um sich geltend zu machen, etwas Neues zu Markte bringen; dies besteht oft bloss darin dass es das bisher geltende Richtige umstosst, um seine Flausen an die Stelle zu setzen; bisweilen gelingt es auf kurze Zeit und dann kehrt man zum alten Richtigen zurück." Ook Goethe vel 'n oordeel wat vir ons weinig vleiend is as hy sê: "Alles Gescheite ist schon gedacht worden, man muss nur versuchen es noch einmal zu denken."

Ons wil ons, egter, in ons bespreking bepaal by die natuurwetenskap. Wat is natuurwetenskap? Natuurwetenskap is navorsing en leer, en besit as 't ware ' $n$ dubbele gesig. Die een gesig verkondig in verhewe bedaardheid aan die wêreld die waarhede, wat verkry is deur navorsing, terwyl die ander gesig in gespanne afwagting die wisselspel van die navorsing aanskou.

Dikwels word gespreek van die tempel van die wetenskap, dit moes eerder gewees het die arena van die wetenskap, waarin die meningsverskille, deur die navorsing veroorsaak, 'n felle stryd laat ontbrand. Voor 
hierdie arena staan nou die Januskop van die natuurwetenskap en weerspieël in die wisselende uitdrukkinge van die twee gesigte die lewe van die wetenskap. Selde is so 'n teenspreking op die twee gesigte sigbaar gewees as juis vandag.

Die lerende gesig verkondig nog steeds die ou, afgesaagde sprokie van die Moniste:-Eens op 'n tyd was daar ' $n$ vis, wat aan wal gespoel werd,- toe het hy verander in 'n molg-en die molg het dan steeds weer en weer. verander totdat hy 'n aap geword het en dié aap 'n mens. Vir hierdie proses was geen God nodig nie, ergo, God bestaan nie.

Hierdie leer begin, egter, die toehoorders buitekant die arena langsamerhand te verveel, en in plaas van op die Januskop te let luister hulle na die woeste lawaai wat vanuit die arena tot by hulle weerklink. Die tweede gesig van die Januskop sien met ontsteltenis neer op die gevegsterrein in die arena, waar steeds nuwe waarhede en leerstellings opduik om mekaar verbitterd te bestry.

Wat het geword van die welomlynde wêreldbeeld, met die son as middelpunt van die wêreldgeheel, waaromheen die aarde saam met die ander planete gedraai het? Destyds het die oneindige ruimte die sterrewêrelde omsluit, en in 'n onveranderlike simmetrie het die tyd verloop. Die eter het die liggolwe van die een gesternte oorgedra op die ander.

Dit het nou alles heeltemal verander. Elke ster wil nou self die centrum wees van die wêreldgeheel. Die ruimte het egter geword en het vorm aangeneem, wat afhanklik is van die tyd. Ons het nou geen voorstelling meer nie van die wêreld omdat daar geen eenparige tyd meer bestaan nie, en ons geen wêreldoorlosie meer besit nie, maar elke ster sy eie oorlosie het. In hierdie nuwe vierdimensionele ruimte-tyd-formasie soek ons te vergeef's na 'n steunpunt vir ons voorstelling. Ruimte $\epsilon n$ tyd waarin dinge veilig gesweef het, het eienskappe van die dinge geword, en hierdie dinge werk ook nie meer volgens die kousaliteitswet op mekaar in nie, maar volgens die waarskynlikheid, wat slegs statisties bepaal kan word. 
Die meganiek van die wêreld het in duie geval. Met krag en stof kan die wêreld nie beheer word nie--nou word as hulp die vorm gebruik. Maar sy vorm besit niks aanskouliks meer nie en dien slegs daartoe om die wêreldgebeurtenisse in formules te begrawe. Ook die subjekte het hulle ro! uitgcspec!. Die nuwe leer ken alleen nog die werklikheid van dinge.

Nog aarsel die lerende Januskop om aan die wêreld die waarhede van formules te verkondig, want 'n wêreldbeskouing bestaan nie meer nie as aanskouing verlore gegaan het, maar alleen 'n wêreldberekening, wat nou klop en dan weer nie klop nie.

Teen die seëvierende matematikus op die puinhoop van die ou wêreldbeskouing het 'n nuwe teenstander verskyn wat hom toeroep: die formule kan nooit en nimmer die doel van die natuurwetenskap wees nie-'n formule is slegs ' $n$ blote aanduiding, hoe 'n proses matematies kan behandel word, maar geen kennis.

Volgens Schopenhauer is wetenskap "ein System von Erkenntnissen, d.h. ein Ganzes von verknüpften Erkenntnissen, im Gegensatz des blossen Aggregats derselben." Hoe kan hierdie kennis dan verkry word? Ook hierop antwoord Schopenhauer as hy sê: „Bei mir ist durchaus die Anschauung die Quelle aller Erkenntnis, der Kern aller Erkenntnis ist die anschauende Auffassung", of "alle tiefe Erkenntnis, sogar die eigentliche Weisheit, wurzelt in der anschaulichen Auffassung der Dinge".

Waarvoor het ons dan wetenskap nodig? Goethe gee ons die antwoord: "Die Wissenschaft hilft uns vor allem, dass sie das Staunen, wozu wir von Natur berufen sind, einigermassen erleichtere, sodann aber, dass sie dem immer gesteigerten Leben neu Fertigkeit erwecke zur Abwendung des Schädlichen und Einleitung des Nutzbaren. Nur durch eine erhöhte Praxis sollten die Wissenschaften auf die äussere Welt wirken-sie alle können nur durch Verbesserung irgend eines Tuns exoterisch wirken." Dit is eienaardig dat dit juis die digter en filosoof Goethe is wat hierdie konneksie van die wetenskap met die lewe, die praktiese uitwerking van wetenskaplike kennis op dis menslike behoeftes en verrigtinge verkondig. 
Kennis kan alleen verkry word deur die aanskouing van dinge. Aanskouing is altyd 'n uiting van 'n lewende subjek. Sonder subjekte bestaan daar geen dinge nie, want alle eienskappe van dinge is volgens hul wese sinsgewaarwordinge van ' $n$ subjek. Wat is hardheid, kleur en geur van ' $n$ ding anders as menslike gewaarwording wat ons toeslryf aan dinge?

Die taak van die wetenskap is tog immers om aan sy tydperk 'n afgeslote, afgeronde wêreldbeeld to gee. Daarby is dit van minder belang of hierdie wêreidbeeld 'n absolute juiste is, want alle wêreldbeelde is tog op die duur min of meer 'n hipotese; wat, egter, van belang is, is dat hierdie wêreldbeeld bevrediging gee en alle lewensuitinge van sy tyd omvat.

Kant het al geleer dat ruimte en tyd slegs vorme van ons eie beskouinge is waarmee ons 'n wêreld wil opbou. Kousaliteit weer is die vorm van ons denke waardeur ons ons meester maak van ons ondervindinge. Ruimte en tyd is streng verbonde aan dia subjek en besit generlei absolute werklikheid. Hierdie kennis vorm die grondslag van die Biologie. As dit die geval is, dan kesit elke subjek sy eie ruimte en sy eie tyd, wat die vir hom geskikte raamwerk van sy wêreld vorm. Daar bestaan nie so iets as 'n absolute wêreld nie, hoewel die meganistiese wêreldbeskouing alle poginge aangewend het om 'n wêreldbeeld te ontwerp, maar tallose omwêrelde van die afsonderlike subjekte. Dit is dan die taak van die Biologie om hulle na te vors.

Die Biologie wys 'n bestaan van 'n van die subjek onafhanklike wêreldtoneel van die hand en ken aan elke subjek sy eie toneel toe. Daardeur sak ook die sprokie van die vis wat 'n molg geword het inmekaar, want vis en molg leef in heeltemal verskillende wêrelde wat nie willekeurig omgeruil kan word nie. In die plek van die een wêreld van die Moniste ontstaan 'n nuwe Universum, wat uit duisende en weer duisende van omwêrelde bestaan, wat almal weer volgens een grootse plan inmekaar gevoeg is. Tegelykertyd ontstaan uit die begraafplaas van formules, waarin die matematici alle lewe wil begrawe, die nuwe beskouing van die wêreldgeheel, gedra deur 'n geheimsinnige planmatigheid van die natuur. Ruimtes en tye bly bestaan, bestaan bly ook die ryk kwa- 
liteite van dinge-geure-kleure en geluide. Maar hulle is nie alleen oorsaaklik met mekaar verbind nie, maar cok planmatig inmekaar geweef tot duisendvoudig skitterende wêrelde, waarvan die rykdom alles wat tot nou toé geweets het oorstraal. Die wêreide van die Amoebae, waarin slegs amoeba-dinge gevind woid, is baie klein en eenvoud:g. Op hulle volg steeds veelvoudiger wordend, die rêrelłe van kreefte, insekte, ens. Maar orals geld dieselfde wet. Die omwêreld van kreefte is omgeef deur 'n kreefteruimte en gevul met kreeftedinge,-Die wêreld ran lrewers is omgeef deur 'n kewerruimte en gevul met kewerdinge. So styg die wêrelde tot hondewêrelde, apewêrelde en mensewêrelde. Ons mag, egter, nooit uit die oog verloor nie dat ons van hierdie oorborrelende rykdom van die natuur slegs 'n baie klein gedeelte te sien kry, nl. die mensedinge.

Hcewel ons soveel van die Biologie verwag, moet ons openlik erken dat die biologie self op die oomblik in 'n kritieke toestand verkeer. Tot omtrent die begin van die 20ste eeu was die vaste geloof dié dat Darwinisme die sleutel was vir alle biologiese probleme. Vandat die eksperimentele navorsing tot in sy besonderhede die stamboomkonstruksies vervang het, het eers die volle moeilikhede van die probleme op die voorgrond getree. In die ontwikkelingsmeganiek het dit dan eers gelei tot 'n nuwe optrede van die Vitalisme en daarna tot daardie menigte van instellinge en opvattings wat die teenswoordige geteoretiseer in die biologie kenmerk. Ons feitekennis van die lewende is enorm en neem nog steeds toe. Wetenskappe soos die fisiese chemie van die sel, die ontwikkelings-meganiek, die genetika, het in betreklik min jare 'n fynheid van die metodiek bereik, wat besonder gunstig vergelyk met die metodes van die anorganiese wetenskappe, en het ' $n$ byna nie meer oorsigtelike hoeveelheid van eksperimentele resultate gelewer. Ons vind, egter, dat ons op biologiese gebied slegs in enkele gevalle-b.v. by die erflikheidsleer-die wettigheid van die gedrag van ons objekte in 'n presiese vorm kan wenroce. Hocvel die fisiho-chemiese navorsing van die lewensprosesse vanaf Harvey se fonderende ontdekking van die bloedsomloop tot die moderne resultste van die biclogiese kollö̈ed-ione-ensiemechemie 
gelei het tot 'n onafgebroke aaneenskakeling van grootse navorsings, bly nogtans die mening bestaan dat die eintlike biologiese probleme en wette nog skaars aangeroer is. Verder vind ons dat die afsonderlike gebiede van die biologie dikwels sonder enige vaste samehang langsmekaar staan, dat die begrippe, wat in die afsonderlike takke van die navorsing aangewend word, teenoor mekaar heeltemal kontingent is, selfs dat nou en dan, wat die een navorser van een gebied met sekerheid meen om geregtig te wees om aan te neem, in direkte teenstelling staan tot die eise en gevolgtrekkinge van 'n naburige gebied. Tegelyk oorsaak en gevolg van hierdie toestand is, dat opinies juis oor die mees algemene vraagstukke in die biologie die mees uiteenlopendes is. Uor die mees algemene grondingesteldhede tot die biologiese probleme so as hulle saamgevat word onder meganisme, vitalisme, seleksie, teleclogie ens., is eindelose diskussies gevoer, sonder dat wesenlik ander resultate verkry is, as dat ook vandag nog byna elke navorser sy min of meer skerp omlynde privaat opinies het, wat meer bepaal word deur onwetenskaplike, wêreldbeskouende, filosofiese gevoels- en wilmatige motiewe as deur saaklike, aan die wetenskap van die Biologie toebehorende, redes. Elkeen is dan natuurlik ook heeltemal oortuig daarvan dat hy alleen in besit is van die wetenskaplike bewyse van sy beskouing, terwyl hy sy teenstander beskou as die dupe van vooroordeel, dogmatismes, slegte filosofie en soortgelyke subjektiewe faktore. Dit maak 'n sintese van die teenstellinge tot ' $n$ algemeen aanneembare leer haas onmoontlik.

G. T. S. EISELEN.

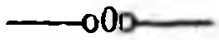

